\title{
New Pelleted Plant-Based Fertilizers for Sustainable Onion Production
}

\author{
Stanisław Kaniszewski* , Irena Babik, Józef Babik \\ Department of Vegetable Cultivation \& Nutrition, Research Institute of Horticulture, Poland
}

Received July 10, 2019; Revised October 16, 2019; Accept October 23, 2019

Copyright $@ 2019$ by authors, all rights reserved. Authors agree that this article remains permanently open access under the terms of the Creative Commons Attribution License 4.0 International License

\begin{abstract}
Pelletized plant-based fertilizers Ekofert K (red clover) and Ekofert L (lucerne) was compared to non-fertilized control and mineral N-fertilization $(100 \mathrm{~kg} \mathrm{~N}$ ha-1) in sustainable onion cultivation (2012-2013). The organic fertilizers at pre-plant rates equivalent to 120,180 and $240 \mathrm{~kg} \mathrm{~N}$ ha-1 were applied on a field fertilized with compost (25 t ha-1). The fertilizers Ekofert $\mathrm{K}$ and $\mathrm{L}$ significantly increased onion production as compared to the basic fertilization with compost alone. The increase in yield was favorably correlated with the applied fertilizer rates. The lowest rate of organic fertilizers ensured a yield at the level of mineral fertilization at the rate of $100 \mathrm{~kg} \mathrm{~N}$ ha- 1 as single application. The higher rates of Ekofert $\mathrm{K}$ and L (180, $240 \mathrm{~kg} \mathrm{~N}$ ha-1) resulted in a marketable yield increase relative to single mineral fertilization. The use of organic as well as mineral fertilization increased nitrogen and chlorophyll contents in onion leaves, compared to the non-fertilized control treatment. The increase was positively correlated with fertilizer rates. The $\mathrm{N}^{-\mathrm{NO}_{3}}$ content in onion bulbs was in general not influenced by the application of organic fertilizers, compared to non-fertilized control treatment. Nitrogen content in the top soil $(0-30 \mathrm{~cm})$ was the highest after 5 weeks from incorporation of the fertilizers and diminished in following 4 weeks on average by $46 \%$ due to plant development and intensive nutrient uptake. After onion harvest, continued mineralization of soil organic matter and lack of uptake by plants increased average nitrogen content nearly to the level at stage of early plant growth. The $\mathrm{N}-\mathrm{NO}_{3}$ content in soil increased with rates of the Ekofert fertilizers. In subsoil horizon $(30-60 \mathrm{~cm})$, the $\mathrm{N}-\mathrm{NO}_{3}$ content was 2.5 times lower than in topsoil and significant only for the highest rate of the fertilizers.
\end{abstract}

Keywords Organic Fertilizers, Onion, Yield, Soil Nitrogen

\section{Introduction}

Agricultural activities are perceived as main sources of soil and ground water pollution, which caused not only by excessive application of mineral fertilizers and synthetic pesticides but also by other non-biodegradable means, which has caused lot of threats to soil quality, fertility and biological activity [Savci 2012; Sun et al. 2012; Pastén-Zapata et al. 2014]. To reduce this negative environmental impact and to improve soil fertility, inputs of different forms of organic matter to soils are recommended. In long-term application, the input of organic matter significantly increases soil carbon content and decreases nitrogen leaching as compared to conventional farming with mineral fertilization only [Laird et al. 2010; Lim et al. 2015]. Nitrogen losses by leaching in conventional agro-ecosystems are about $20 \mathrm{~kg}$ per ha per year, which are $50 \%$ higher than organic systems based on to incorporate in soil from leguminous biomass or cattle manure [Drinkwater et al., 1998].

Organic matter has a positive impact on soil physical, chemical and biological functions such as soil structure, aggregate stability, water holding capacity, cation exchange capacity, buffering capacity, biological activity, etc. [Krull et al. 2004]. Combined organic and mineral fertilization over long periods increase and stabilize humus content in soils [Tomov and Artinova, 2005]. In organic and integrated crop production the main sources of nutrients available for cultivated crops are soil organic matter and applied organic fertilizers. [Yassen and Khalid, 2009]. Organic fertilizers such as animal manure, green manure or compost has added directly to soils either pre planting or in the autumn after harvesting the plants [Splittstosser, 1990]. However, due to the special regulation for organic and integrated production, the use of animal manure is restricted to pre-plant application only (EC No 834/2007). Traditionally fresh green manures can be used as forecrop or intercrop incorporated into the soil. Their application, on the other hand, is not easy because 
they are wet and heavy, not easy to handle and not storable. Further, they need to be decomposed in soils within a few weeks before nutrients are available for vegetable plants. The alternative practice is the use of organic fertilizers with specific attributes (high nutrient concentration, low $\mathrm{C} / \mathrm{N}$ ratio, good storability, easy handling), produced from chopped, dried green manures, and suitable for fertilizing crops and incorporating into the soil [Sorensen and Thorup-Kristensen, 2010].

The objective of the present study was to assess the effects of two new pelletized organic plant-based fertilizers produced from dried biomass of red clover and lucerne on the growth, yield and quality of onion, as well as on the availability and migration of nutrients in the soil profile within the plant growth period.

\section{Materials and Methods}

Field experiments were conducted in 2012 and 2013 at the Research Institute of Horticulture in Skierniewice, central Poland. Experiment was conducted on a sandy-loam soil. Onion cv. Alonso $\mathrm{F}_{1}$ (Bejo Zaden, NL) was grown from module transplants (3 plants/cell) and planted in the field on April 25, 2012 and April 29, 2013. Before planting, the experimental field was fertilized with 25 t of plant compost per hectare.

The experiment involved in randomized complete block design with four replications. The experimental factors were: pelletized organic fertilizers Ekofert $\mathrm{K}$ and $\mathrm{L}$ produced from red clover meal and lucerne meal, respectively. The nutrient NPK contents of DM in both fertilizers were 3.1, 0.2, and 3.0 and 3.5, 0.2, 3.1, percent respectively. The fertilizers were applied in onion cultivation as pre-plant treatments equivalent to 120,180 and $240 \mathrm{~kg}$ of nitrogen per one hectare. The effective of the organic fertilizers was compared with conventional mineral fertilization at a rate of $100 \mathrm{~kg} N$ per hectare applied as a single pre-plant treatment or split in two rates, each of $50 \mathrm{~kg} \mathrm{~N}$ per hectare, applied as pre-plant and side-dressing, and with the control plot without any additional fertilization (except fertilization with compost incorporated as part of the basic treatment of the whole field area). All this constituted the following nine experimental treatments subjected to assessment in the study:

1. Ekofert K $120 \mathrm{~kg} \mathrm{~N} / \mathrm{ha}$

2. Ekofert K $180 \mathrm{~kg} \mathrm{~N} / \mathrm{ha}$

3. Ekofert K $240 \mathrm{~kg} \mathrm{~N} / \mathrm{ha}$

4. Ekofert L $120 \mathrm{~kg} \mathrm{~N} / \mathrm{ha}$
5. Ekofert L $180 \mathrm{~kg} \mathrm{~N} / \mathrm{ha}$

6. Ekofert L $240 \mathrm{~kg} \mathrm{~N} / \mathrm{ha}$

7. Control $100 \mathrm{~kg} \mathrm{~N} / \mathrm{ha}$

8. Control $50+50 \mathrm{~kg} \mathrm{~N} / \mathrm{ha}$

9. Control (non-fertilized)

The cultivated onion plants were regularly irrigated when soil water tension reached $0,03 \mathrm{MPa}$. A single water rate amounted $20 \mathrm{~mm}$. During vegetation, plant development, chlorophyll index and nitrate nitrogen content in leaves were recorded. A single harvest of onion was carried out and plant weight, total and marketable yields, and the quality of bulbs were determined. At harvest, the nitrate nitrogen content in onion bulbs was analyzed as well.

Soil analyses of nitrate nitrogen $(0-30 \mathrm{~cm}$ and 30-60 cm depth) were performed twice in the growing period with a 4 weeks interval i.e. one month after planting and after the harvest. The $\mathrm{N}^{-} \mathrm{NO}_{3}$ content was determined with the colorimetric method using a Scan Plus flow analyzer. The chlorophyll index was measured with a SPAD 502 chlorophyll meter (Konica-Minolta, Japan).

The results of the experiment were subjected to factor analysis of variance with the significance of the means tested with the Newman-Keuls test at $\mathrm{P}=0.05$.

\section{Results and Discussion}

\subsection{Chlorophyll Content}

The organic fertilizers Ekofert K and Ekofert L used for onion cultivation resulted in increase of chlorophyll content of leaves (SPAD index measured at 50-60 days after planting). The increase in fertilizer rates to 180 and $240 \mathrm{~kg} \mathrm{~N} / \mathrm{ha}$ as well as the application of mineral fertilization significantly influenced the chlorophyll content in the leaves in both research years. The only exception was Ekofert $\mathrm{K}$ at the rate of $180 \mathrm{~kg}$ N/ha in 2012 and single mineral fertilization in 2013. There was no significant difference in the index value between the rates of 180 and $240 \mathrm{~kg}$ N/ha for both kinds of Ekofert fertilizers and mineral fertilization (100 kg N/ha and 50+50 kg N/ha) in 2012, but in 2013 there was no significant difference for the divided mineral fertilization only. This was probably due to heavy rainfall in early spring in 2013, which contributed to considerable leaching of available nitrogen from the soil profile, especially when Ekofert $\mathrm{K}$ was applied at the single pre-plant rate (fig.1 and 2). 


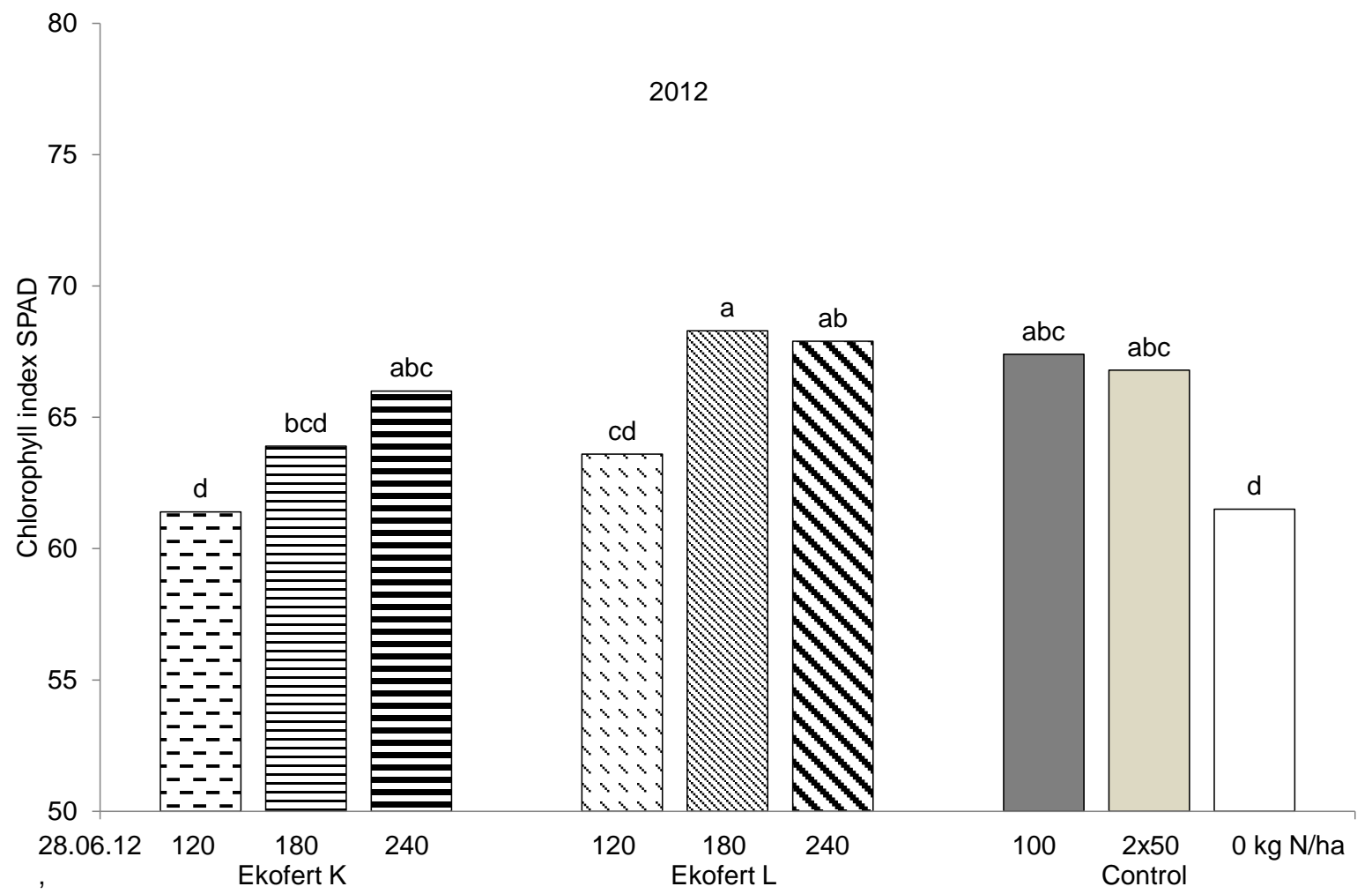

Figure 1. The influence of applied fertilization on the value of the chlorophyll index of onion leaves (2012)

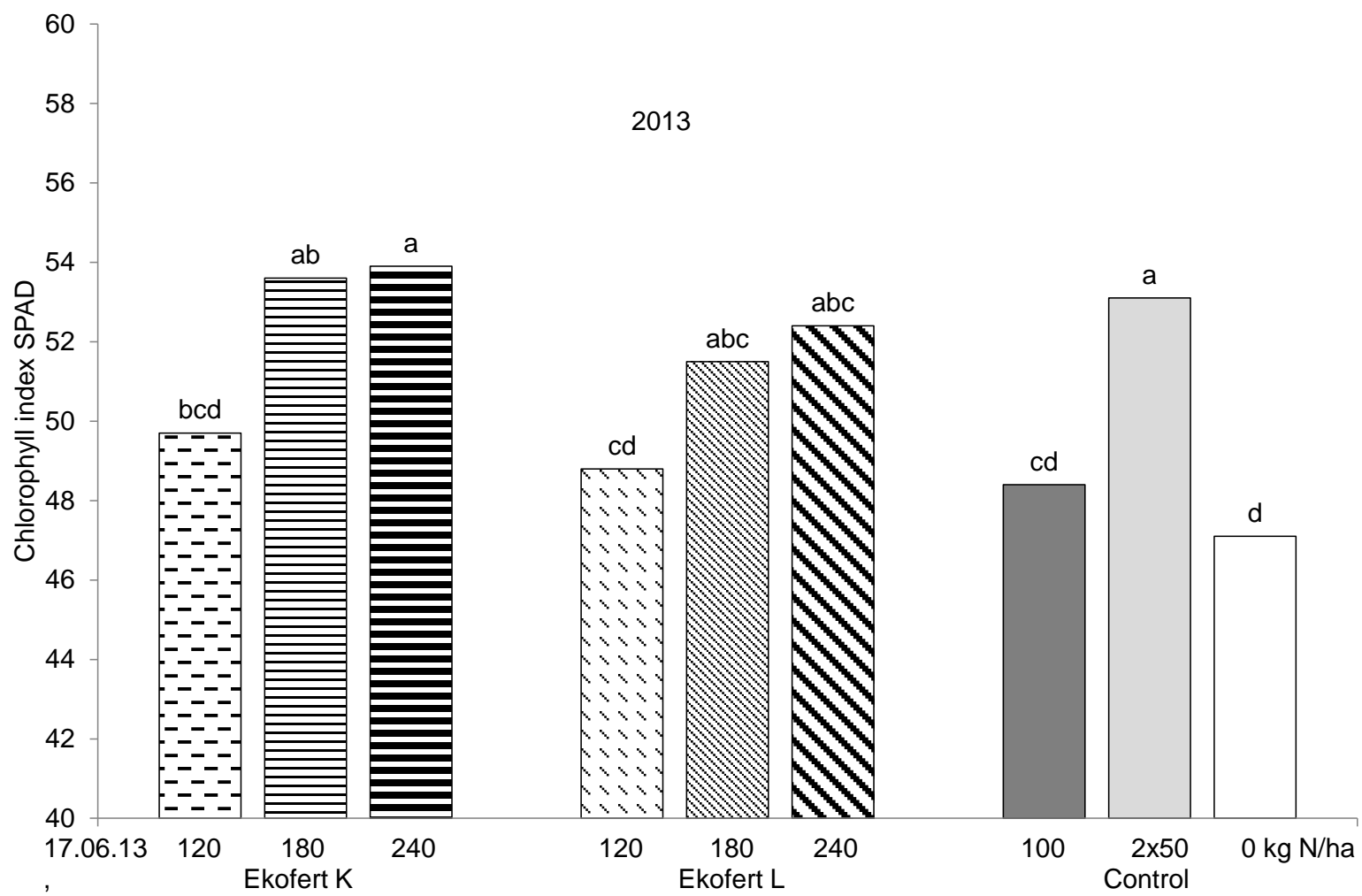

Figure 2. The influence of applied fertilization on the value of the chlorophyll index of onion leaves (2013) 
Follet et al. [1981], in a study on nutrient absorption by crop plants and its relation to chlorophyll content, indicated that chlorophyll coloration is related to the amount of nutrients absorbed by the plant from the soil. Singh et al. [2007] reported a significant increase in the chlorophyll content in potato leaves with increasing $\mathrm{N}$ fertilization (mineral). Those studies concluded that the significance of the correlation between SPAD values, chlorophyll content and leaf tissue $\mathrm{N}$ depended on plant growth stage and the earliness of the variety. For an early variety, the best time for the detection of chlorophyll and $\mathrm{N}$ content in the leaves seems to be the middle of the variety's growing period. Siavoshi and Laware [2013] found that chlorophyll content and rice yield significantly increased with organic or mineral fertilizers applied alone or in combination. However, the maximum grain yield and higher chlorophyll content were noted in plants treated with a mixture of cattle and poultry manure supplemented with half a dose of the recommended chemical fertilizer. This was in agreement with earlier results of Ramesh et al. [2002], who emphasized that greater chlorophyll values in the leaves treated with organic manure + NPK are of importance because photosynthetic activity and crop yield may increase with increased chlorophyll content of the leaves.

\section{2. $\mathrm{N}-\mathrm{NO}_{3}$ Content in Leaves}

As well as the chlorophyll content, the $\mathrm{N}-\mathrm{NO}_{3}$ content in onion leaves was also influenced by fertilization. The use of organic as well as mineral fertilization increased the nitrogen content in onion leaves compared to the non-fertilized control treatment. For the lowest dose of Ekofert (120 kg N/ha), the $\mathrm{N}-\mathrm{NO}_{3}$ content in the leaves was at a level similar to that obtained with mineral fertilization. As the doses of the organic fertilizers rose, the nitrogen content in onion leaves was raised too and was the highest for the highest nitrogen rate (240 kg N/ha). Considerable increases in the $\mathrm{N}-\mathrm{NO}_{3}$ content at the highest dose of Ekofert occurred in the year 2013, characterized by heavy rainfall in the springtime and delayed onion development caused by hail (fig. 3 and 4). Aisha et al. [2007] had concluded that increasing the rates of a nitrogen fertilizer in the soil around the rooting zone caused an increase in the solubility and availability of nutrients, thus increasing the absorption of the nutritional elements in plant tissues.

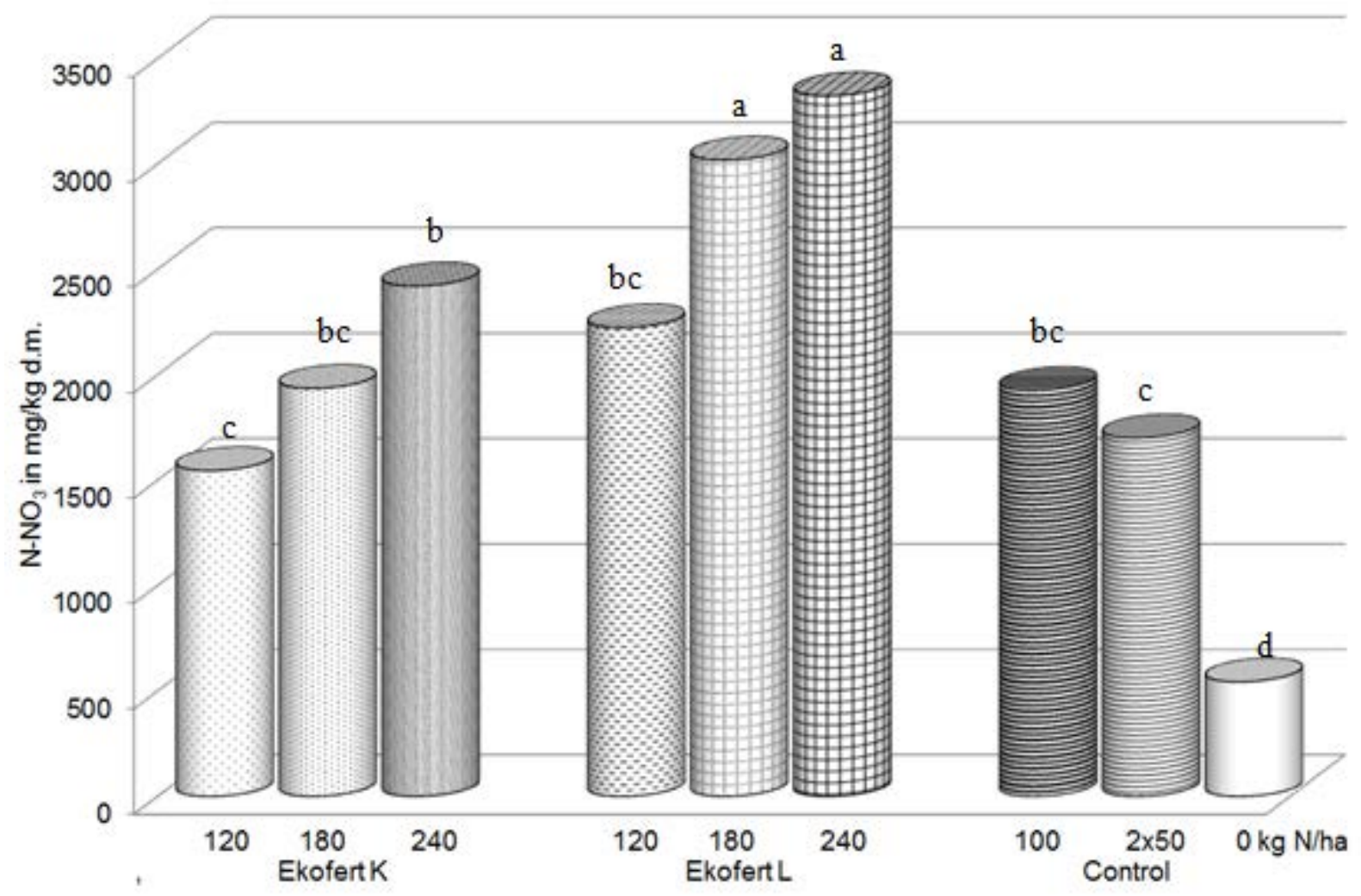

Figure 3. Nitrogen $\left(\mathrm{N}-\mathrm{NO}_{3}\right)$ content in the leaves of onion (2012) 


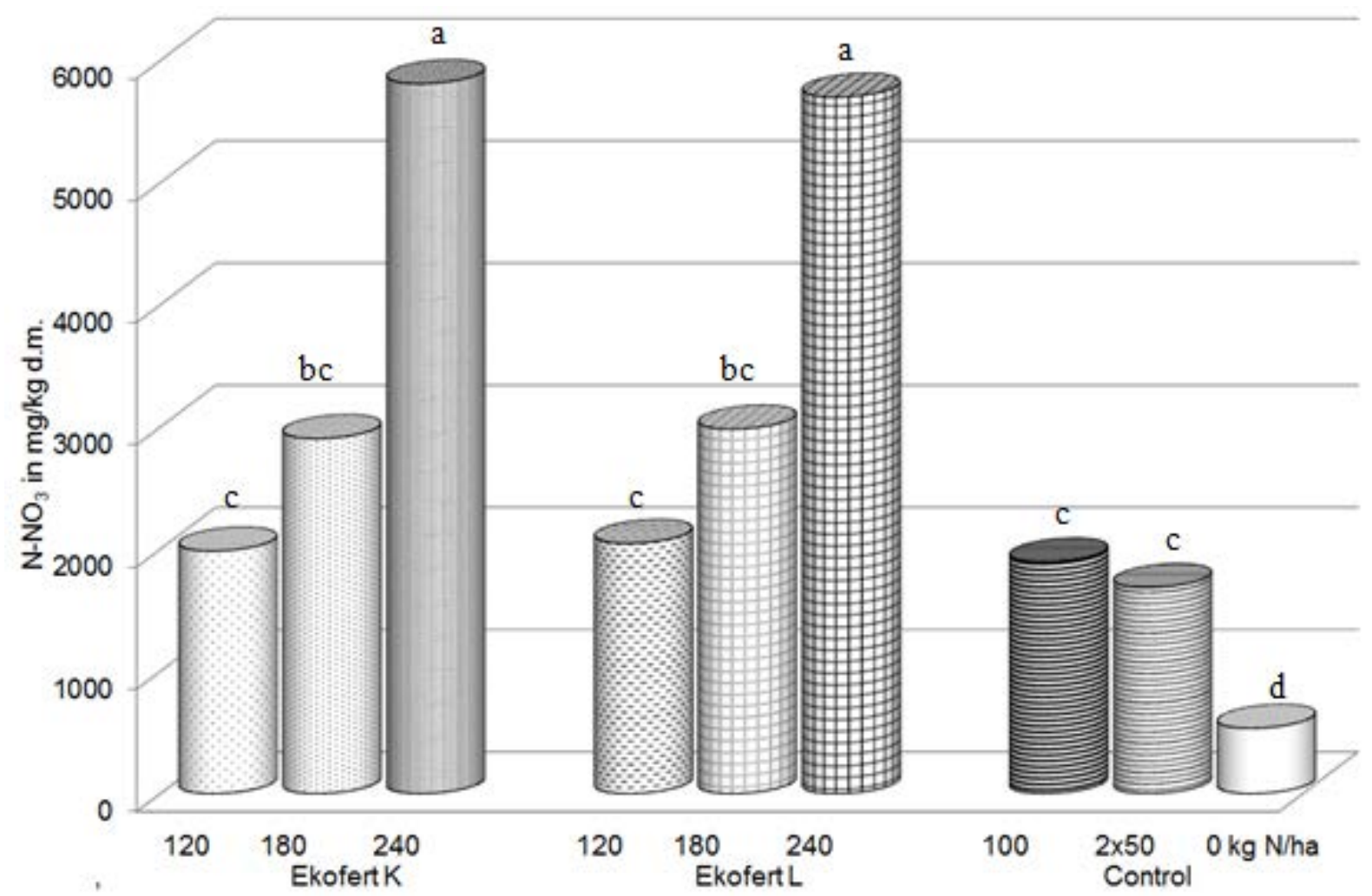

Figure 4. Nitrogen $\left(\mathrm{N}-\mathrm{NO}_{3}\right)$ content in the leaves of onion (2013)

\subsection{Marketable Bulb Yield}

In both years of the research, the organic fertilizers Ekofert $\mathrm{K}$ and Ekofert L significantly increased the marketable yield of onion compared to the non-fertilized control. Yield increase was favourably correlated with the dose of fertilizer and ranged from 17 to $28 \%$ in 2012 and from 40 to $61 \%$ in 2013. Only in 2012, the increase in yield proved not to be significant for Ekofert $\mathrm{L}$ in the dose of 120 $\mathrm{kg} \mathrm{N} / \mathrm{ha}$. In relation to the conventional mineral fertilization at $100 \mathrm{~kg} \mathrm{~N} / \mathrm{ha}$, applied as a single basic fertilization treatment, significant differences in marketable yield were produced by Ekofert $\mathrm{K}$ and $\mathrm{L}$ at the rates of 180 and $240 \mathrm{~kg} \mathrm{~N} / \mathrm{ha}$. Compared to the mineral fertilization applied in split doses $(50+50 \mathrm{~kg} \mathrm{~N} / \mathrm{ha})$, the yield increase obtained with the Ekofert fertilizers was statistically insignificant although the amount of available nitrogen applied in the organic fertilizers was much lower than in the mineral one (fig. 5 and 6). These results are consistent with those obtained in an earlier study on celeriac cultivation [Kaniszewski at al., 2013] in which a better yield effect was obtained with higher organic fertilization. Aisha et al. [2007] had also reported that the application of organic nitrogen (town refuse manure) at a higher rate and supplemented with natural $\mathrm{P}$ and $\mathrm{K}$ at high rates as well caused a great effect on onion growth, total bulb yield and its physical and chemical properties. The experiment by Abdelrazzag [2002] had shown that the application of sheep manure or mineral fertilizer resulted in the same yield of onion bulbs, while the impact of chicken manure was a little worse. In Swiss research, slightly higher yields of different field crops, grown in a 7-year crop rotation, were obtained by applying a pure organic fertilizer (farmyard, liquid manure) than with pure mineral or organic-mineral fertilizers [Spiess et al. 2011]. The study by Nugllie et al. [2011] showed that vermicomposting, among other manures (farmyard, poultry and pig), proved to be the only treatment producing by itself onion yields equivalent to those obtained under the recommended mineral fertilization. A plant-based fertilizer such as faba bean meal produced the same potato yield and tubers with a slightly increased starch content, compared to farmyard manure [Raupp and Oltmanns, 2006]. Sorensen and Thorup-Kristensen [2010] reported increases in the yields of leek and celery with increasing rates of organic fertilizers (green manures such as silage or chopped dry); however, the yield response was determined by the $\mathrm{C} / \mathrm{N}$ ratio of green manures. A low $\mathrm{C} / \mathrm{N}$ ratio, preferably below 12, effected quick release of nutrients from fertilizer biomass. 


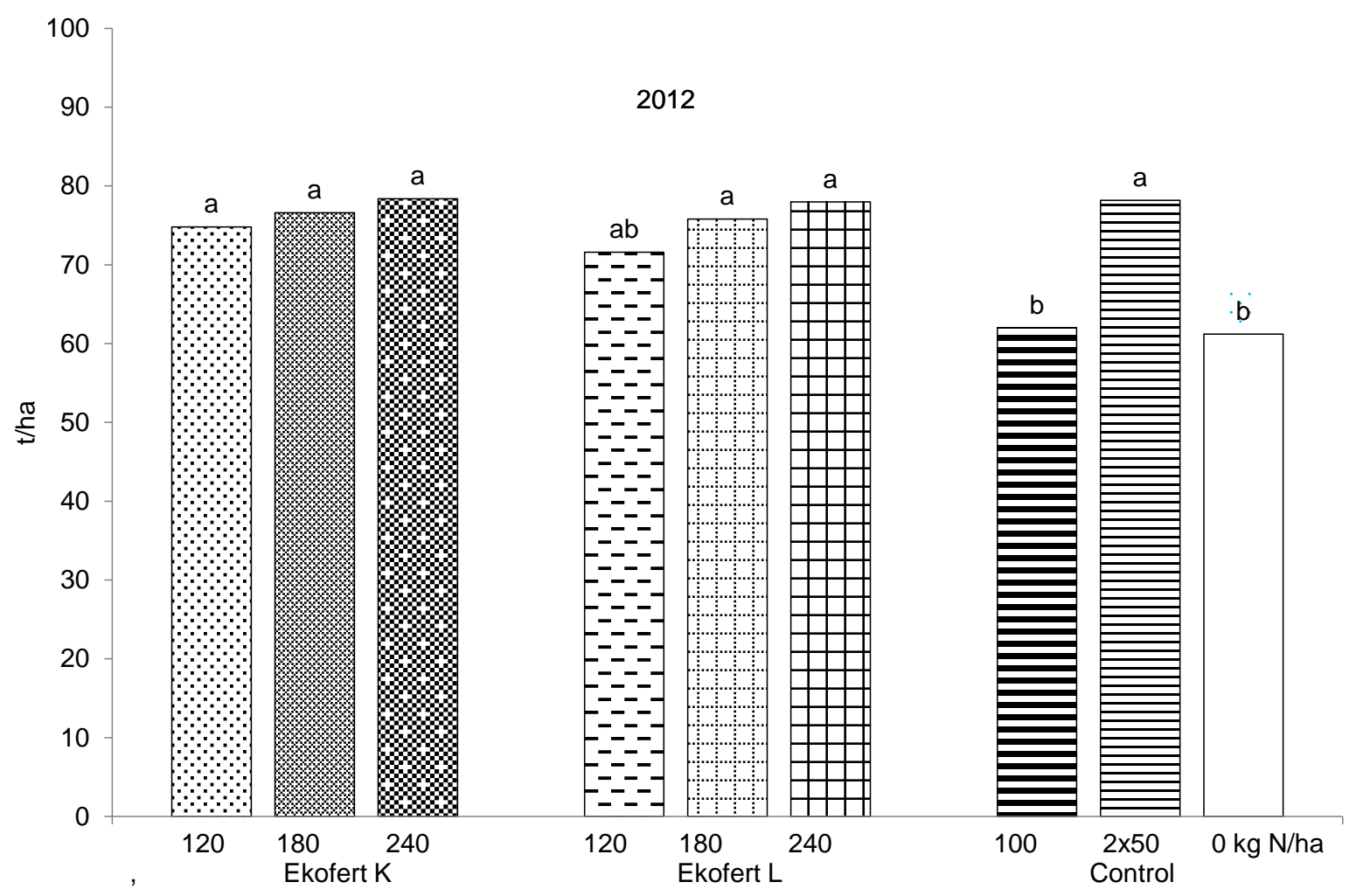

Figure 5. The influence of Ekofert fertilizers on the marketable yield of onion in 2012

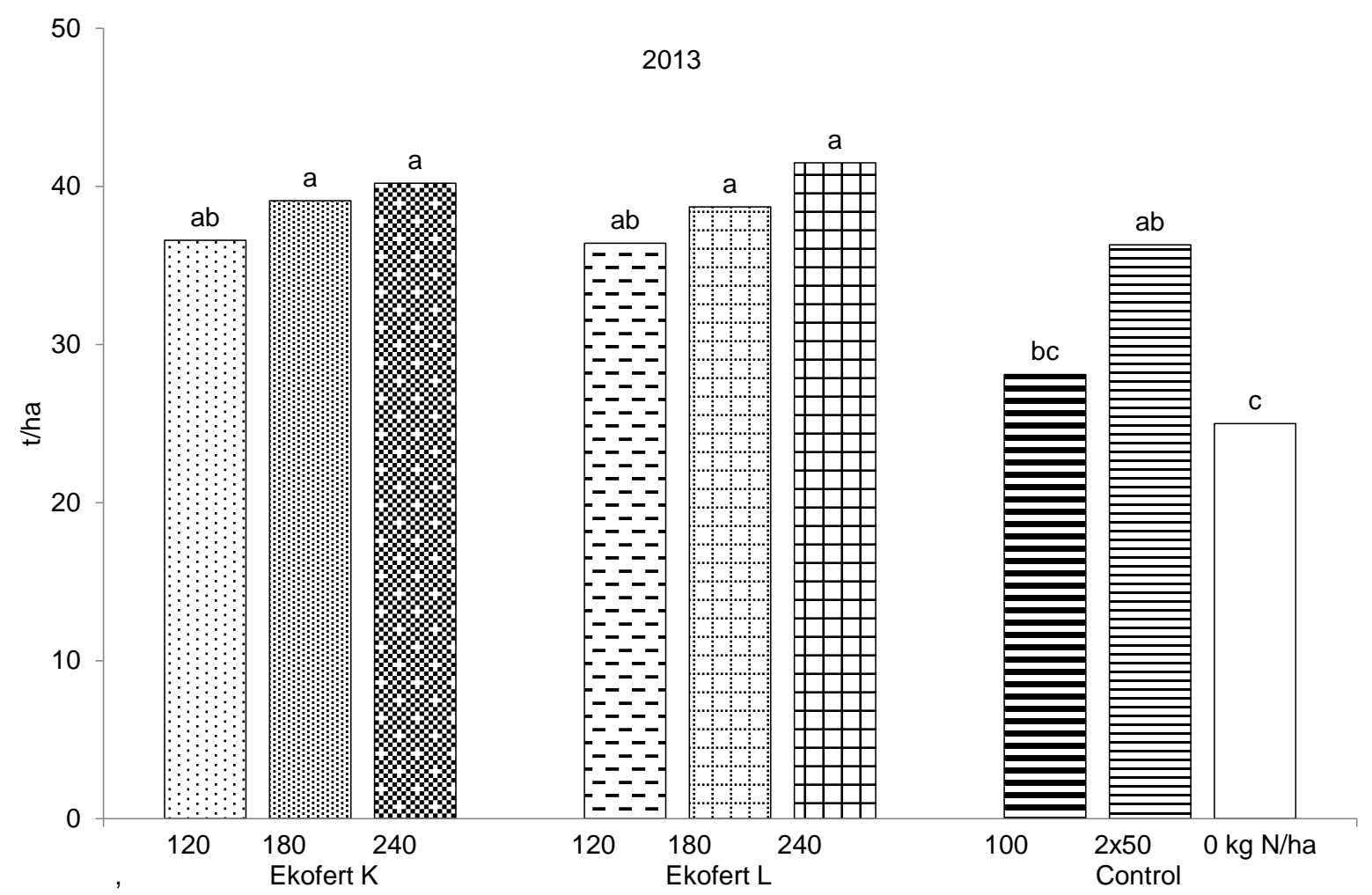

Figure 6. The influence of Ekofert fertilizers on the marketable yield of onion in 2013 


\section{4. $\mathrm{N}-\mathrm{NO}_{3}$ Content in Onion Bulbs}

The $\mathrm{N}-\mathrm{NO}_{3}$ content in the harvested onion bulbs depended on the applied fertilizers and rates, and was more diverse in 2012 (20.0-50.8 $\mathrm{mg} \mathrm{N} / \mathrm{kg}$ d.m.) than in 2013 (50.0-62.5 mg N/kg d.m.). In 2012, a significant increase in $\mathrm{N}-\mathrm{NO}_{3}$ content was affirmed only between the onion bulbs harvested from the plots with mineral fertilizer applied at the single rate of $100 \mathrm{~kg} \mathrm{~N} / \mathrm{ha}(50.8 \mathrm{mg} \mathrm{N} / \mathrm{kg}$ d.m.) and those from the non-fertilized control plots $(20 \mathrm{mg}$ $\mathrm{N} / \mathrm{kg}$ d.m.). A considerable increase in the $\mathrm{N}-\mathrm{NO}_{3}$ content in onion bulbs ( $40.0 \mathrm{mg} \mathrm{N} / \mathrm{kg} \mathrm{d.m}$.) was also obtained with split mineral fertilization $(50+50 \mathrm{~kg} \mathrm{~N} / \mathrm{ha})$, but its significance was not proven. Application of the Ekofert organic fertilizers increased the $\mathrm{N}-\mathrm{NO}_{3}$ content in onion bulbs compared to the non-fertilized control; however, in relation to mineral fertilization the increase was generally lower and depended on fertilizer rate. For the rate of $120 \mathrm{~kg}$ $\mathrm{N} / \mathrm{ha}$, it ranged from $29 \mathrm{mg} \mathrm{N} / \mathrm{kg}$ d.m. for Ekofert K to 32.8 $\mathrm{mg} \mathrm{N} / \mathrm{kg}$ d.m. for Ekofert L; however, in the case of $240 \mathrm{~kg}$
$\mathrm{N} / \mathrm{ha}$, it amounted to 40.5 and $47.3 \mathrm{mg} \mathrm{N} / \mathrm{kg}$ d.m. respectively, but the differences were not statistically proven (fig 7). In 2013, the increase in the $\mathrm{N}-\mathrm{NO}_{3}$ content in onion bulbs as a result of mineral fertilization, compared to the unfertilized control, ranged from 7.8 to $12.5 \mathrm{mg} \mathrm{N} / \mathrm{kg}$ d.m. for the single and split application respectively, but a significant impact was proven only for the split rate. The differences in the effect of single and split fertilization compared to the previous year resulted from different weather conditions. Heavy precipitation in the early spring of 2013 contributed to significant leaching and limited availability of mineral nitrogen applied at the single rate. Organic fertilization with the Ekofert fertilizers, in relation to the non-fertilized control, increased the nitrogen content in onion bulbs in the range of $2.4-2.9 \mathrm{mg} \mathrm{N} / \mathrm{kg} \mathrm{d} . \mathrm{m}$. for the rate of $120 \mathrm{~kg} \mathrm{~N} / \mathrm{ha}$, and $7.5-11.0 \mathrm{mg} \mathrm{N} / \mathrm{kg}$ d.m. for the highest rate of $240 \mathrm{~kg} \mathrm{~N} / \mathrm{ha}$. Significant impact was proven only for Ekofert L at the highest rate (240 kg N/ha) (fig.8).

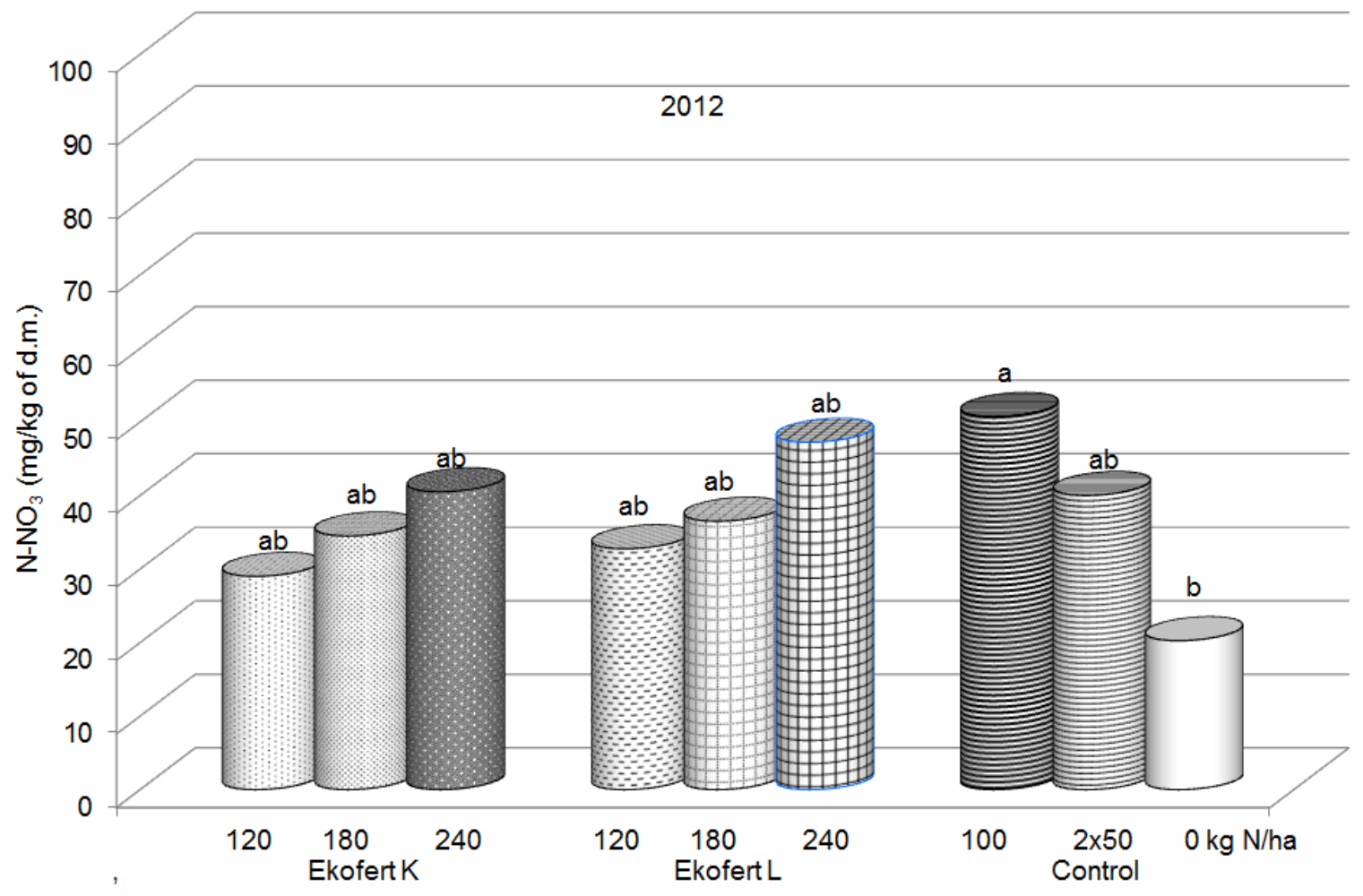

Figure 7. N-NO $\mathrm{NO}_{3}$ content in onion bulbs as an effect of applied fertilizers (2012) 


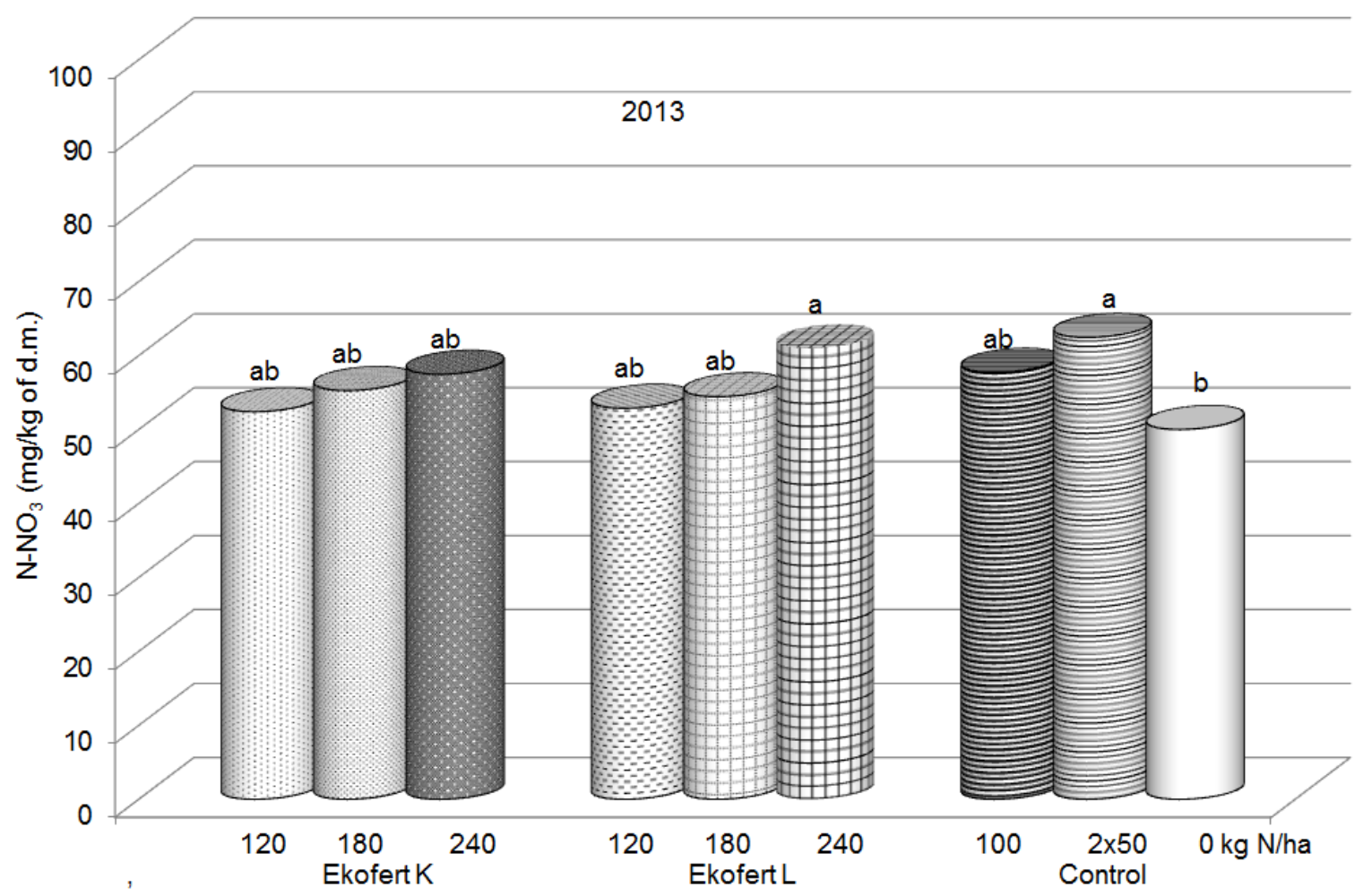

Figure 8. N-NO $\mathrm{NO}_{3}$ content in onion bulbs as an effect of applied fertilizers (2013)

The increase in nitrogen in onion tissue with increasing application rates of organic manures had been reported earlier by Abdelrazzag [2002] and Aisha et al [2007]. Combined application of farmyard and chicken manure improved the growth of onion plants and the chemical composition of bulbs in terms of essential oil and NPK content in a study by Yassen and Khalid [2009]. Positive effects of different organic fertilizers (farmyard, poultry manures and plant compost) on the nutritional value and total antioxidant capacity of cabbages and cucumbers were also reported by Pavla and Pokluda [2008].

\subsection{N-NO ${ }_{3}$ Content in Soil Profile}

The organic plant-based fertilizers used in the study significantly affected the $\mathrm{N}-\mathrm{NO}_{3}$ content in the soil profile during the whole vegetation season and influenced that content in the onion leaves and bulbs. The results of soil analysis showed changes in nutrient availability during plant growth, depending on the fertilization treatments. At the beginning of plant growth, 5 weeks after incorporating the organic fertilizers into the soil and onion planting, the nitrate nitrogen content in the topsoil horizon $(0-30 \mathrm{~cm})$ was the highest (41.8-79.3 $\mathrm{mg} \mathrm{N}-\mathrm{NO}_{3} / \mathrm{L}$ ) in all the plots, compared to later dates of soil analysis, and then decreased with plant growth and nutrient uptake by the plants. A considerable decrease in the $\mathrm{N}-\mathrm{NO}_{3}$ content in the topsoil horizon was detected after the next 4 weeks of plant growth. At the end of onion growth, when there was a limited nutrient uptake by plants, the $\mathrm{N}-\mathrm{NO}_{3}$ content in the topsoil increased. The lowest $\mathrm{N}-\mathrm{NO}_{3}$ content was found in the non-fertilized control plots. In the mineral fertilized plots and those fertilized with the Ekofert fertilizers, it was higher and depended on the applied rate. In general, the $\mathrm{N}-\mathrm{NO}_{3}$ content in the soil increased with the higher rate of the Ekofert fertilizers (fig. 9). At the end of onion growth and after the harvest, from 35.8 to $61.5 \mathrm{mg} \mathrm{N}-\mathrm{NO}_{3} / \mathrm{L}$ was affirmed in the top soil horizon $(0-30 \mathrm{~cm})$, depending on the applied fertilizers. In the organically fertilized plots, the $\mathrm{N}-\mathrm{NO}_{3}$ content was higher by $4.2-25.7 \mathrm{mg} / \mathrm{L}$ compared to the non-fertilized control plot. But significant differences were obtained only for the highest rate of Ekofert $\mathrm{K}$ and Ekofert L (240 kg N/ha), which increased the nitrate nitrogen content by 23.2 and $25.7 \mathrm{mg} / \mathrm{L}$ of soil respectively. The lower increase in that nutrient varied in the range of 4.2 to $16.2 \mathrm{mg} / \mathrm{L}$ of soil and was obtained with the application of lower fertilizer rates (120 and $180 \mathrm{~kg} \mathrm{~N} / \mathrm{ha}$ ) and with mineral fertilization at the rate of $100 \mathrm{~kg} \mathrm{~N} / \mathrm{ha}$ (single and split), but those differences were not significant (fig. 10). 


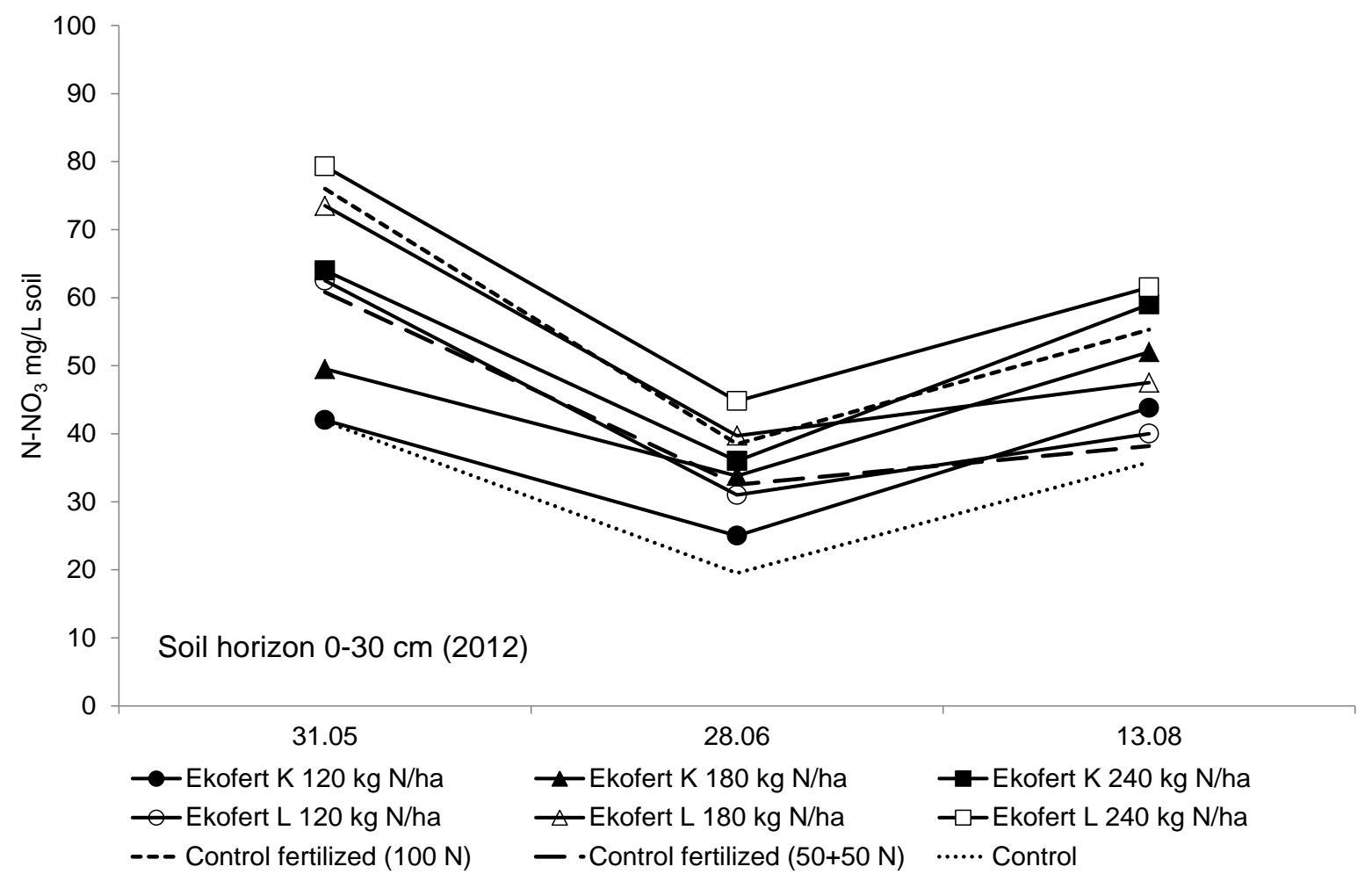

Figure 9. $\mathrm{N}-\mathrm{NO}_{3}$ content in the topsoil horizon during the vegetation season as a result of the applied Ekofert fertilizers (2012)

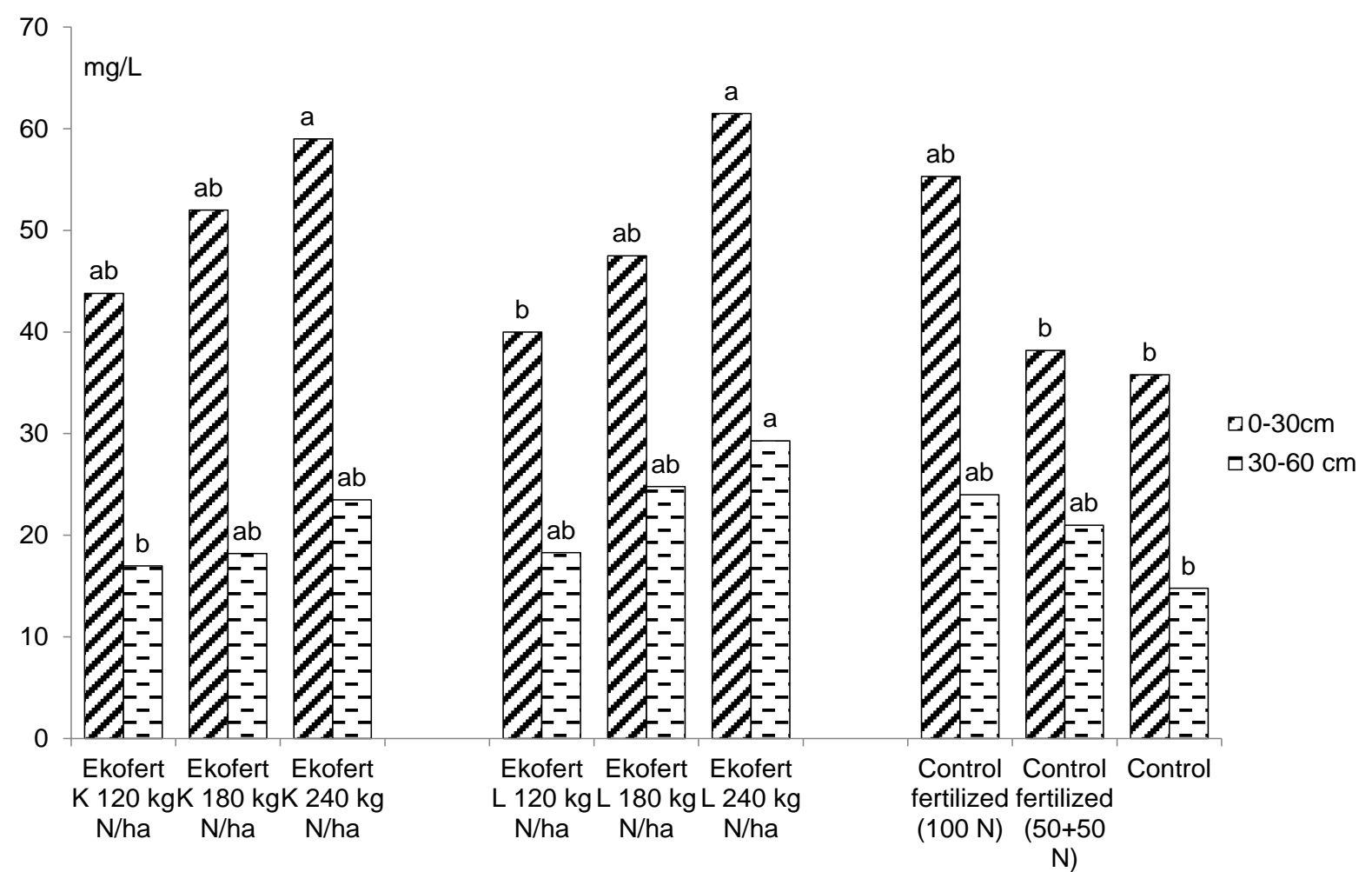

Figure 10. Nitrogen $\left(\mathrm{N}-\mathrm{NO}_{3}\right)$ content in the soil layers $(0-30$ and $30-60 \mathrm{~cm})$ resulting from the applied fertilizers and their rates (13 August 2012) 
In the subsoil horizon $(30-60 \mathrm{~cm})$, the $\mathrm{N}^{-\mathrm{NO}_{3}}$ content was by 1.8 to 2.9 times lower than in the topsoil horizon and ranged from $14.7 \mathrm{mg} / \mathrm{L}$ of soil for the unfertilized control to $17.0-29.3 \mathrm{mg} / \mathrm{L}$ of soil for the fertilized plots (mineral and organic). Compared to the control treatment, a significant increase in that nutrient content occurred only after the application of the fertilizer Ekofert $\mathrm{L}$ at the highest dose (240 kg N/ha) (fig. 10).

Similar results had been obtained in a study with celeriac, where the microbial process after harvest and decomposition of organic matter increased the nitrogen content in the soil profile [Kaniszewski et al., 2013]. Increases in nutrient contents in the soil with increasing application rates of chicken and sheep manure were also reported by Abdelrazzag [2002]. Campbell and Beckett [1988] had explained that the addition of organic waste into the soil resulted in increasing concentrations of macronutrients in the topsoil because organic waste contains higher concentrations of essential nutrients than most soils.

In the case of onion, a shallow-rooted crop plant of a short growing period, mineralization of organic fertilizers after harvest will release later in the growing season some amount of nutrients susceptible to leaching. This risk could be avoided by cultivating a second crop in the autumn. Drinkwater et al. [1998] reported that nitrogen losses due to leaching were comparable in legume-based and manure-based systems, averaging $13 \mathrm{~kg} \mathrm{~N} / \mathrm{ha}$, but in a fertilizer-driven system they were $50 \%$ higher. Abdelrazzag's [2002] findings from the onion study emphasized that using manures coupled with drip irrigation is an alternative cropping system that can provide high yields and reduce inorganic fertilizer inputs in vegetable production.

\section{Conclusions}

Organic fertilizers Ekofert K and Ekofert L, produced form dried biomas of red clover and lucerne had a positive effect on yield of onion. The efficacy of organic fertilizer was equivalent to mineral fertilization of $100 \mathrm{~kg} \mathrm{~N}$ per hectare when applied at lowest rate of $120 \mathrm{~kg} \mathrm{~N}$ per hectare and was significantly higher when applied at 180 and 240 kg $\mathrm{N}$ per hectare

The use of organic as well as mineral fertilization increased nitrogen and chlorophyll contents in onion leaves, compared to the non-fertilized control treatment.

The organic fertilizers Ekofert $\mathrm{K}$ and Ekofert $\mathrm{L}$ increased the $\mathrm{N}-\mathrm{NO}_{3}$ content in the topsoil compared to the non-fertilized control and provided better availability of nutrients within the growing period of onion. The effect of the fertilizers was positively correlated with fertilizer rates.

After the onion harvest (short-season crop), the Ekofert organic fertilizers applied in the highest dose (240 kg N/ha) increased the $\mathrm{N}-\mathrm{NO}_{3}$ content in the topsoil by $64-72 \%$ compared to the non-fertilized control, but by only $7-11 \%$ compared to mineral fertilization.

Application of the Ekofert organic fertilizers, even in the high doses, did not cause subsoil pollution by nutrient leaching and had no negative impact on soil environment.

\section{REFERENCES}

[1] Abdelrazzag A., 2002. Effect of chicken manure, sheep manure and inorganic fertilizer on yield and nutrient uptake by onion. Pakistan Jour. of Biology. Sci. 5(3):266-268.

[2] (Pdf accessed 2006.03.23) http://198.170.104.138/pjbs/200 2/266-268.pdf.

[3] Aisha A.H., Fatma A., Rizk A.M., Shaheen and Mona M. Abdel-Mounty., 2007. Res. Jour. of Agri. and Bio. Sci. 3:380-388. http://www.aensiweb.com/old/rjabs/rjabs_septoct_2007.html.

[4] Campbell D.J., Beckett P.H.T., 1988. The soil solution in a soil treated with digested sluge. J. Soil. Sci., 39: 283-298.

[5] Drinkwater L.E., Wagoner P., Sarrantonio M., 1998. Legume-based cropping system have reduced carbon and nitrogen losses. Nature vol. 396:262-265.

[6] Follet R.H., Murphy L.S. Donalue R.L., 1981. Soil-fertilizer-plant relationship. Fertilizer Soil Amendment. 6 (16): 478-481.

[7] Kaniszewski S., Babik I., Babik J., 2013: Pelletized legume plants as fertilizer for vegetables in organic production. NUTRIHORT: Nutrient management, innovative techniques and nutrient legislation in intensive horticulture for an improved water quality. Ghent, September 16-18, 2013, s. 330-336.

[8] Krull E.S., Skjemstad J.O., Baldock J.A., (Pdf accessed 2004.11.09). Functions of soil organic matter and the effect on soil properties. Grains Research \& Development Corporation project No CSO 00029. p.129.

[9] Laird D, Fleming P, Wang B, Horton R, Karlen D. 2010. Biochar impact on nutrient leaching from a Midwestern agricultural soil. Geoderma 158: 436-442.

[10] Lim SL, Wu TY, Lim PN, Shak KPY. 2015. The use of vermicompost in organic farming: overview, effects on soil and economics. J Sci Food Agric 95: 1143-1156.

[11] www.grdc.com.au/ /media/05FCOF23498E4129AC216A0 682C804E3.pdf.

[12] Ngullie E., Singh V.B., Singh A.K., Singh H., 2011. Fertilizing for sustainable onion production systems. Better Crops/Vol. 95, (2011, No1): 7-9.

[13] Official Journal of the European Union., 2007. Council Regulation (EC) No 834/2007 of 28 June 2007 on organic production and labeling of organic products and repealing Regulation (EEC) No 2092/91. L189/1.

[14] Pastén-Zapata E, Ledesma-Ruiz R, Harter T, Ramírez AI, Mahlknecht J. 2014. Assessment of sources and fate of nitrate in shallow groundwater of an agricultural area by 
using a multi-tracer approach. Science of The Total Environment 470-471: 855-864.

[15] Pavla B., Pokluda R., 2008.Ifluence of alternative Organic Fertilizers on antioxidant capacity in head cabbage and cucumber. Not. Bot. Hort. Agrobot. Cluj 36(1):63-67. (available at www.notulaebatanicae.ro).

[16] Ramesh K, Chandrasekaran B., balasubramanian T.N.,Bangarusamy U., Sivasamy R., Sankaran N., 2002. Chlorophyll Dynamics in rice (Oryza sativa) before and after flowering based on SPAD (chlorophyll) meter monitoring and its relation with grain yield. J. Agron. Crop Sci. 188:102-105.

[17] Raupp J., Oltmanns M., 2006. Effects of plant based organic fertilizer (faba bean meal) compared to farmyard manure on yield and quality of potatoes and soil organic levels. Poster at: Joint Organic Congress, Odense, Denmark, May 30-31, 2006. http://orgprints.org/7596.

[18] Savci S. 2012. An Agricultural Pollutant: Chemical Fertilizer. International Journal of Environmental Science and Development 3(1): 77-80.

[19] Sun B, Zhang L, Yang L, Zhang F, Norse D, Zhu Z. 2012. Agricultural non-point source pollution in China: causes and mitigation measures. AMBIO 41: 370-379.

[20] Siavoshi M., Laware S.L., 2013. Role of organic fertilizers on chlorophyll content in rice (Oryza sativa L). Trends in Life Sciences Volume 2 Issue-3 (2013). http://sciencejourn al.in/data/documents/TLS-Vol-2-3-3_1pdf .

[21] Singh, Rachna J.P., Lal S.S., Ray S.S., Panigrahy S., 2007. Using leaf chlorophyll meter for $\mathrm{N}$-fertilizer management in precision farming potato. Potato J. 34 (3-4):221-226.

[22] Sørensen J.N., Thorup-Kristensen K., 2010.Plant-based fertilizer for organic production. Proc.4th IS on Ecol. Fert. Strat. Field Veg. Prod. (Ed.: R.U. Larsen) Acta Hort. 852, ISHS 2010: 195-199.

[23] Spiess E., Prasuhn V., Stauffer W., 2011. Influence of organic and mineral fertilizers on nutrient leaching. Agrofarung Schweiz 2 (9):376-381.

[24] Splittstosser W.,E., 1990. Vegetable growing handbook: Organic and traditional method. 3rd edition. An AVI Book. New York. USA.

[25] Tomov T., Artinova N., 2005. Fffect of system mineral and organic-mineral fertilization on the humus content and fractions inn mollic fluvisoils. J. Cent. Eur. Agric. (2005):6:4, 577-582.

[26] Yassen A.A., Khalid Kh.A., 2009. Influence of organic fertilizers on the yield, essential oil and mineral content of onion. Int. Agrophysics 23:183-188. 